\title{
EFFECT OF SOIL INTERACTING HERBICIDES ON SOYBEAN NODULATION IN BALCARCE, ARGENTINA ${ }^{1}$
}

\author{
NORMA GONZALEZ2 ${ }^{2}$ JUAN JOSE EYHERABIDE³, MARIA IGNACIA BARCELONNA ${ }^{4}$, \\ ALFREDO GASPARI ${ }^{4}$ and SILVINA SANMARTINO 5
}

\begin{abstract}
Two trials were performed in Balcarce, Argentina ( $37^{\circ} 45^{\prime} \mathrm{LS} ; 58^{\circ} 18^{\prime} \mathrm{LW}$ ) during 1993-94, to assess the effect of eight herbicides applied individually or in tank mixtures, on nodule number, nodule dry weight, seed yield and $\mathrm{N}$ percent in seed in soybean Asgrow 3205, inoculated with Bradyrhizobium japonicum CB 1809. Individual herbicides and doses in $\mathrm{kg} \mathrm{ha}^{-1}$ of a.i. were metribuzin (0.48), acetochlor (0.90), metolachlor (1), flumioxazin (0.075), trifluralin (0.96), imazaquin $(0.20)$, imazethapyr $(0.10)$ and chlorimuron ethyl $(0.0125)$. The mixtures were metribuzin+acetochlor $(0.48+0.9)$, flumioxazin + acetochlor $(0.075+0.9)$, imazaquin + acetochlor $(0.2+0.9)$, metribuzin+metolachlor $(0.48+1.92)$, and flumioxazin + metolachlor $(0.075+1.92)$. A control treatment without herbicides was included. Both trials were laid out as randomized complete blocks with four replicates, on a loam illitic thermic petrocalcic Paleudoll, 5.7\% organic matter (OM), 25\% clay, $30.4 \mathrm{cmol} \mathrm{kg}^{-1}$ CEC. Nodules were sampled at V2 (second node), V6 (sixth node) and R5 (beginning seed) growth stages. Herbicides did not significantly affect the beginning of nodulation or nodule number and mass at R5, not either grain yield or $\mathrm{N}$ accumulation. This indicates lack of interference between soil interacting herbicides and $\mathrm{N}$ fixation in the high organic matter, loam soils of SE Buenos Aires province, even though a tendency in less number and dry weight of nodules was evident at the two latter growth stages.
\end{abstract}

Index terms: Bradyrhizobium japonicum, herbicides injury, nitrogen fixation, yield.

\section{EFEITO DE ALGUNS HERBICIDAS QUE INTERAGEM COM O SOLO, SOBRE A NODULAÇÃO DA SOJA EM BALCARCE, ARGENTINA}

RESUMO - Durante 1993-94 realizaram-se dois experimentos em Balcarce, Argentina (37 $45^{\prime}$ LS; $58^{\circ} 18^{\prime} \mathrm{LO}$ ) para avaliar o efeito de oito herbicidas, aplicados isoladamente ou em misturas, sobre o número e peso de nódulos, rendimento e percentagem de N nos grãos de soja Asgrow 3205 que receberam inoculação da estirpe CB1809 de Bradyrhizobium japonicum. Os herbicidas aplicados isoladamente e suas doses em $\mathrm{kg} \mathrm{ha}^{-1}$ de i.a. foram metribuzin $(0,48)$, acetochlor $(0,90)$, metolachlor $(1)$, flumioxazin $(0,075)$, trifluralin $(0,96)$, imazaquin $(0,20)$, imazathapyr $(0,10)$ e chlorimuron ethyl $(0,0125)$. As misturas foram metribuzin+acetochlor $(0,48+0,9)$, flumioxazin+acetochlor $(0,075+0,9)$, imazaquin+acetochlor $(0,2+0,9)$, metribuzin+metolachlor $(0,48+1,92)$, e flumioxazin+metolachlor $(0,075+1,92)$. Incluiu-se um controle sem herbicidas. Os experimentos foram conduzidos no delineamento em blocos completos ao acaso, com quatro repetições. Usou-se um solo Paleudol petrocálcico, franco, ilítico, térmico, com matéria orgânica 5,7\%, argila 25\%, e CTC $30,4 \mathrm{cmol} \mathrm{kg}^{-1}$. Os nódulos foram amostrados em V2 (segundo nó), V6 (sexto nó) e R5 (começo de semente). Os herbicidas não alteraram o início da nodulação nem o número ou peso dos nódulos em R5, e também não houve efeito no rendimento de grãos, o que sugere que não há interferência entre eles e fixação de $\mathrm{N}$ nos solos francos com alto conteúdo de matéria orgânica do sudeste de Buenos Aires. Por outro lado, evidenciou-se uma tendência à formação de menos nódulos e menor peso dos nódulos, nos dois últimos níveis de crescimento.

Termos para indexação: Bradyrhizobium japonicum, lesões por herbicidas, fixação de N, rendimento.

${ }_{1}^{1}$ Accepted for publication on June 5, 1998.

2 Agronomist, M.Sc., INTA, Estación Experimental Agropecuaria de Balcarce, cc 276 (7620), Balcarce, Argentina. E-mail: ngonzalez@balcarce.inta.gov.ar

${ }^{3}$ Agronomist, Profesor Asociado, Facultad de CienciasAgrarias,
Universidad Nacional de Mar del Plata, cc 276 (7620), Balcarce, Argentina.

${ }^{4}$ Agronomist, Facultad de Ciencias Agrarias.

${ }^{5}$ Profesora de Matemática, Profesora Adjunta, Facultad de Ciencias Agrarias. 


\section{INTRODUCTION}

Soybean (Glycine max (L.) Merrill.) is a crop of major economic importance in Argentina, where 6 million ha are sown each year, with an average yield of 2,370 $\mathrm{kg} \mathrm{ha}^{-1}$ (Giorda, 1998). In the SE of Buenos Aires province, 100,000 ha are used to cultivate soybean, and this area has a potential yield of $5,500 \mathrm{~kg} \mathrm{ha}^{-1}$ under intensive production (Andriani et al., 1991). If this optimum yield could be generalized, this region would be a major contributor to the national production. Since the crop has been only recently included in crop rotations in this region, its soils are devoid of Bradyrhizobium japonicum. Hence, the inoculated seed has to provide the incoming rhizosphere with enough microorganisms to nodulate and fix nitrogen. Under these conditions, the successful inoculation is critical for the establishment of the symbiosis (Rennie \& Dubetz, 1984). The infective phase of the symbiosis begins just before the contact occurs between bacteria and root hairs (Fisher \& Long, 1992) and during this period, the association is highly sensitive to the soil environment (Keyser et al., 1993). Not only B. japonicum survival but also the whole sequence of events that culminate in nodulation may be affected by changes in the soil environment. Herbicides in the soil, especially those applied preplanting, preemergence and early postemergence may exert adverse influences on the association, depending on the chemical, doses and their interaction with the soil properties (Duniganm et al., 1972; Bollich et al.,1985). Since herbicides are necessary to achieve maximum yields, their influence on nodulation may conflict with the crop management.

The influence of herbicides on nodulation seems to be closely related to the clay and organic matter contents of the soil. Negative effects are associated with sandy soils with less than 2\% OM (Bollich et al., 1985; Moraes et al., 1989). As such effects are site dependent, results ought to be drawn out from experiments carried under field conditions, in the same region in which those results will be applied (Kucey et al., 1988).

Both broad leaves and grass weed seeds are abundant in the soil seed bank in the SE of Buenos
Aires and weed competition with the crop can be severe. For this reason herbicides mixtures are recommended to achieve optimum weed control (Eyherabide, 1993, 1995). Although research has demonstrated that individual herbicides applied to the soil interfere with nodulation (Dunigan et al., 1972 ; Bollich et al., 1985; Han \& Oh, 1989; Moraes et al., 1989; Akhtar et al., 1990; Dalton, 1992; Yueh \& Hensley, 1993), studies about the influence of mixtures of herbicides on the association is scarce.

The present paper reports the results of two field experiments aimed to assess the effect of eight preplanting, preemergence or early postemergence herbicides applied alone or in tank mixtures on the nodulation, grain yield and grain $\mathrm{N}$ accumulation of soybean growing on a high OM, loam soil from SE Buenos Aires province, in Argentina.

\section{MATERIAL AND METHODS}

Field studies were conducted on a Balcarce loam (illitic thermic loam petrocalcic Paleudoll) (United States, 1996), at the Facultad de Ciencias Agrarias-Estación Experimental INTA Balcarce, at SE Buenos Aires province, Argentina ( $37^{\circ} 45^{\prime} \mathrm{LS} ; 58^{\circ} 18^{\prime} \mathrm{LW}$ ), during 1993-94. The soil characteristics were: $\mathrm{pH} 5.94$; P $7.72 \mathrm{mg} \mathrm{kg}^{-1}$; organic matter (OM) 5.7\%; cation exchange capacity (CEC) $30.4 \mathrm{cmol} \mathrm{kg}^{-1}$; sand $34.7 \%$, silt $40 \%$ and clay $25.3 \%$. Climatic information recorded during the soybean growth cycle is shown in Fig. 1 and Table 1.

Soybean cv. Asgrow 3205, inoculated with Bradyrhizobium japonicum strain CB 1809 (109 colony forming units/g inoculant) was sown on November 23, 1993 with a pneumatic seeder, delivering 32 seeds per meter at a depth of $2.5 \mathrm{~cm}$. Both experiments were laid out as randomized complete block designs with four replicates. Plots were $7 \mathrm{~m}$ long x $2.8 \mathrm{~m}$ wide (4 rows spaced $0.7 \mathrm{~m})$. In Experiment 1, herbicides and doses ( $\mathrm{kg} \mathrm{ha}^{-1}$ of i.a.) were as follows: imazaquin $(0.20)$ was surface applied 20 days before planting; trifluralin (0.96), was preplant incorporated; metribuzin (0.48), acetochlor (0.90), metolachlor (1) and flumioxazin (0.075) were sprayed at preemergence; imazethapyr $(0.10)$, and chlorimuron ethyl (0.0125) were applied at early postemergence. In Experiment 2, five mixtures of herbicides were tested, metribuzin+acetochlor $(0.48+0.9)$, flumioxazin+acetochlor $(0.075+0.9)$, metribuzin+ metolachlor $(0.48+1.92)$, flumioxazin + metolachlor 
$(0.075+1.92)$, and imazaquin+acetochlor $(0.2+0.9)$. All mixes were sprayed at preemergence, except imazaquin, which was applied 20 days before planting. Chemicals in both experiments were applied with a $\mathrm{CO}_{2}$ pressure source knapsack plot sprayer, at $197 \mathrm{kPa}$, delivering 150 liter ha-1 through 11002 Teejet nozzles. Each experiment included a control treatment without herbicides. The remaining weeds in all plots were handpulled.

Nodule number and nodule dry weight were recorded at V2, V6 and R5 stages (Fehr \& Caviness, 1977) from plants that were collected from a randomly selected $0.5 \mathrm{~m}$ long portion of a row. At harvest, grain yield and yield components were assessed from plants sampled from the central rows $\left(2.8 \mathrm{~m}^{2}\right)$. Nitrogen concentration in grain was measured by semimicrokjeldhal digestion. Digests were analyzed in a Tecator Kjeltec Auto 1030 Analyzer.

Data were subjected to analysis of variance. The assumptions underlying the analysis of variance were checked through residual analysis. Significance between means was tested using Duncan's Multiple Range Test at $\mathrm{P}<0.05$.

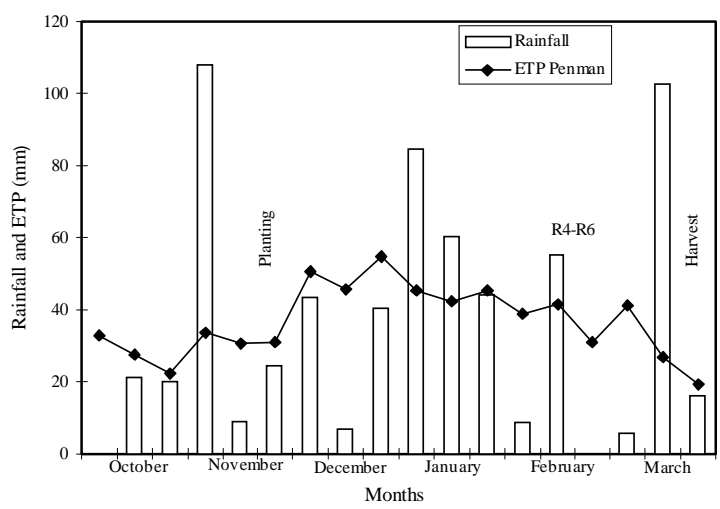

FIG. 1. Rainfall and evapotranspiration (Penman) occurred during the soybean growth cycle.

\section{RESULTS AND DISCUSSION}

The mean values for nodule number and nodule dry weight per plant at V2, V6 and R5 are shown in Figs. 2 and 3, from Experiment 1 and Experiment 2, respectively. Assumptions underlying the ANOVA were supported except in V2 data in which homogeneity of variance was violated. Nevertheless V2 data were subjected to analysis of variance since the model was a balanced, fixed effects one in which the F test is just slightly affected by non homogeneity (Montgomery, 1984).

At R5, when maximum nodulation is accomplished by indeterminate soybean cultivars, nodules number and dry weight per plant in the control plots in both experiments suggest that no limitations interferred with the expression of nodulation other than chemical treatments. These results support previous research data recorded in successful inoculations under potential yield conditions at Balcarce (González, 1994).

In both experiments there was no statistically significant decrease in nodule number or nodule dry weight per plant $(\mathrm{P}>0.05)$ caused by the application of herbicides with respect to the control plots values, except for nodule dry weight in Experiment 2 at R5 $(\mathrm{P}=0.048)$. However, there was a trend that showed that nodule number and weight were lower in the treated plots, especially in Experiment 2. In Experiment 1, imidazolinones (imazaquin and imazathapyr) and trifluralin gave the lowest values of nodule dry weight at R5. These results show the negative effect of the first group of herbicides on nodulation, while trifluralin probably caused damage to root development at early stages of plant

TABLE 1. Air temperature $\left({ }^{\circ} \mathrm{C}\right)$. Means of decadic periods.

\begin{tabular}{cccccc}
\hline \multirow{2}{*}{ Decades } & \multicolumn{5}{c}{ Months } \\
\cline { 2 - 6 } & November & December & January & February & March \\
\hline $1^{\text {st }}$ & 16.1 & 18.3 & 20.0 & 18.5 & 20.8 \\
$2^{\text {nd }}$ & 14.9 & 17.6 & 20.2 & 19.6 & 20.3 \\
$3^{\text {rd }}$ & 15.4 & 19.0 & 20.0 & 21.4 & 15.3 \\
\hline
\end{tabular}


growth (Rennie \& Dubetz,1984; Al-Gubouri \& Habib, 1987; Yueh \& Hensley, 1993).

The characteristics of the soil in which the experiments were carried out (high organic matter and clay content), may have been responsible for the mild effect herbicides had on nodulation through adsorption phenomena mediated by the soil colloids. Besides that, this type of soil exhibited a developed microbial biomass whose metabolism could

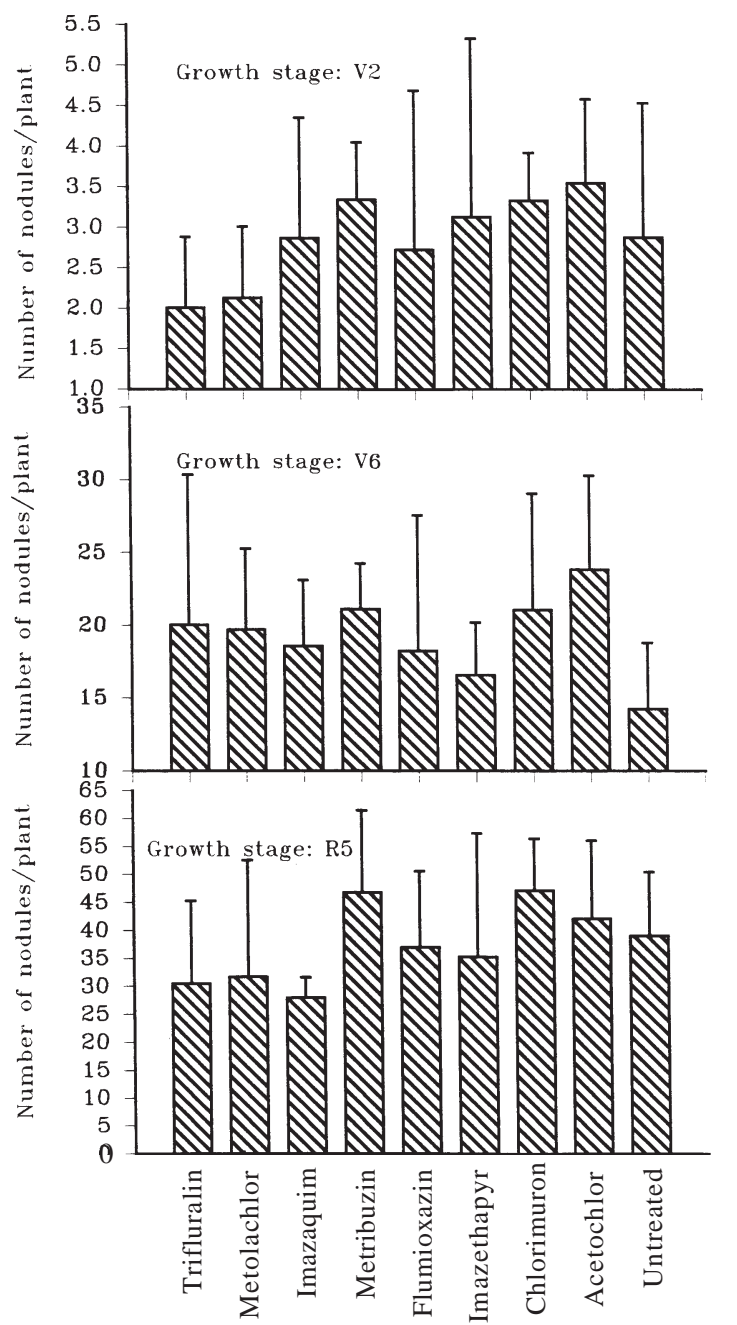

enzimatically degrade the herbicides, causing a dilution effect on the applied doses (Dunigan et al., 1972; Moyer, 1979; Bollich et al., 1985).

Even though both experiments were not statistically comparable, results indicate that the application of mixtures of herbicides may exert a greater detrimental effect on nodulation than those sprayed alone.
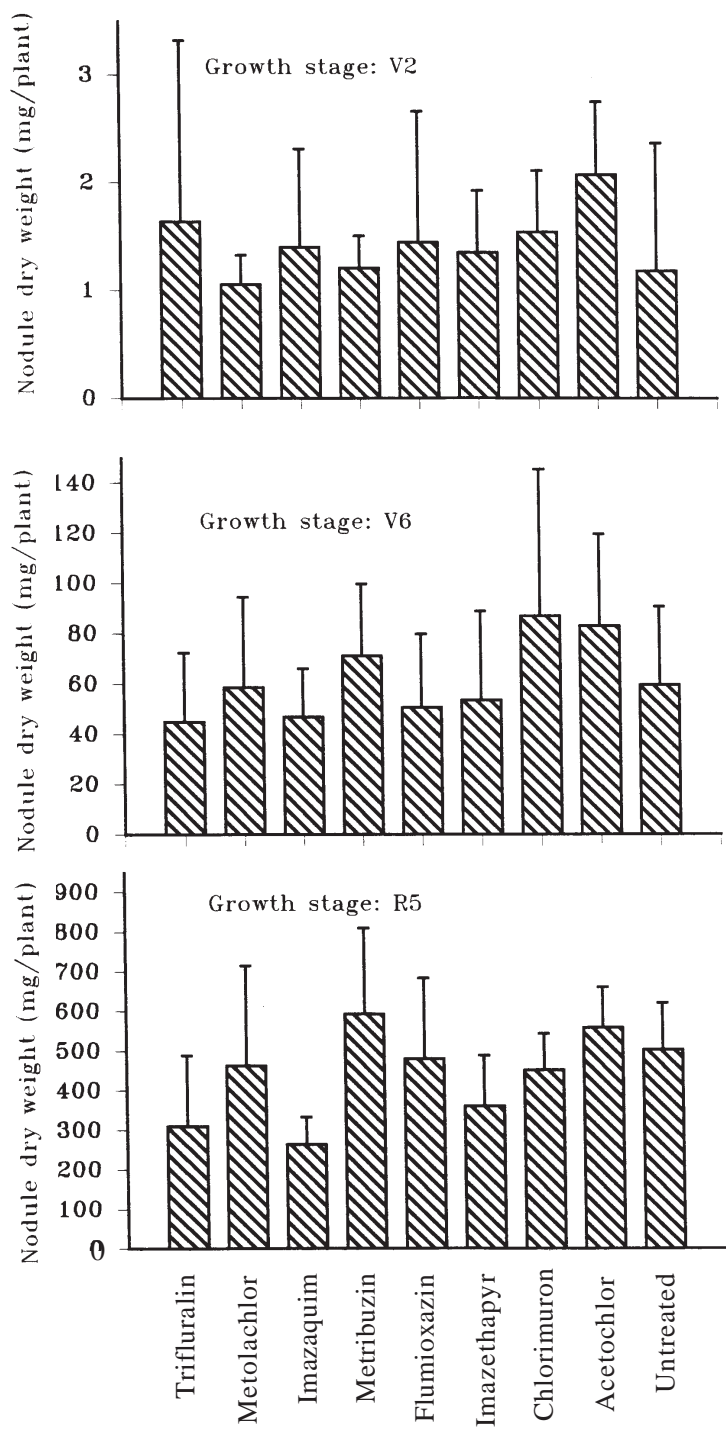

FIG. 2. Mean number and dry weight of nodules per plant of soybean cultivar A3205 inoculated with Bradyrhizobium japonicum CB 1809 at second node (V2), sixth node (V6) and beginning seed (R5) affected by herbicides applied alone. Vertical bars are the standard error of means. 
There were no significant differences between the treatments in grain yield or yield components, $(\mathrm{P}>0.05)$ as a consequence of herbicide application in any experiment (Table 2). Neither $\mathrm{N}$ percent nor $\mathrm{N}$ yield in soybean seed were affected by the application of herbicides at any of the experiments in relation to the control plots (Table 2). Differences in nodulation atributes between treated and control plots (Figs. 2 and 3) were not evident on yield or $\mathrm{N}$ accumulation, probably because the soybean plants assimilated more soil $\mathrm{N}$ to compensate for eventually lower $\mathrm{N}_{2}$ fixation rates as demonstrated by Rennie et al. (1982) and Rennie \& Dubetz (1984).

Treated plots in Experiment 1 yielded about 10\% more than those in Experiment 2. Average $\mathrm{N}$ accu-
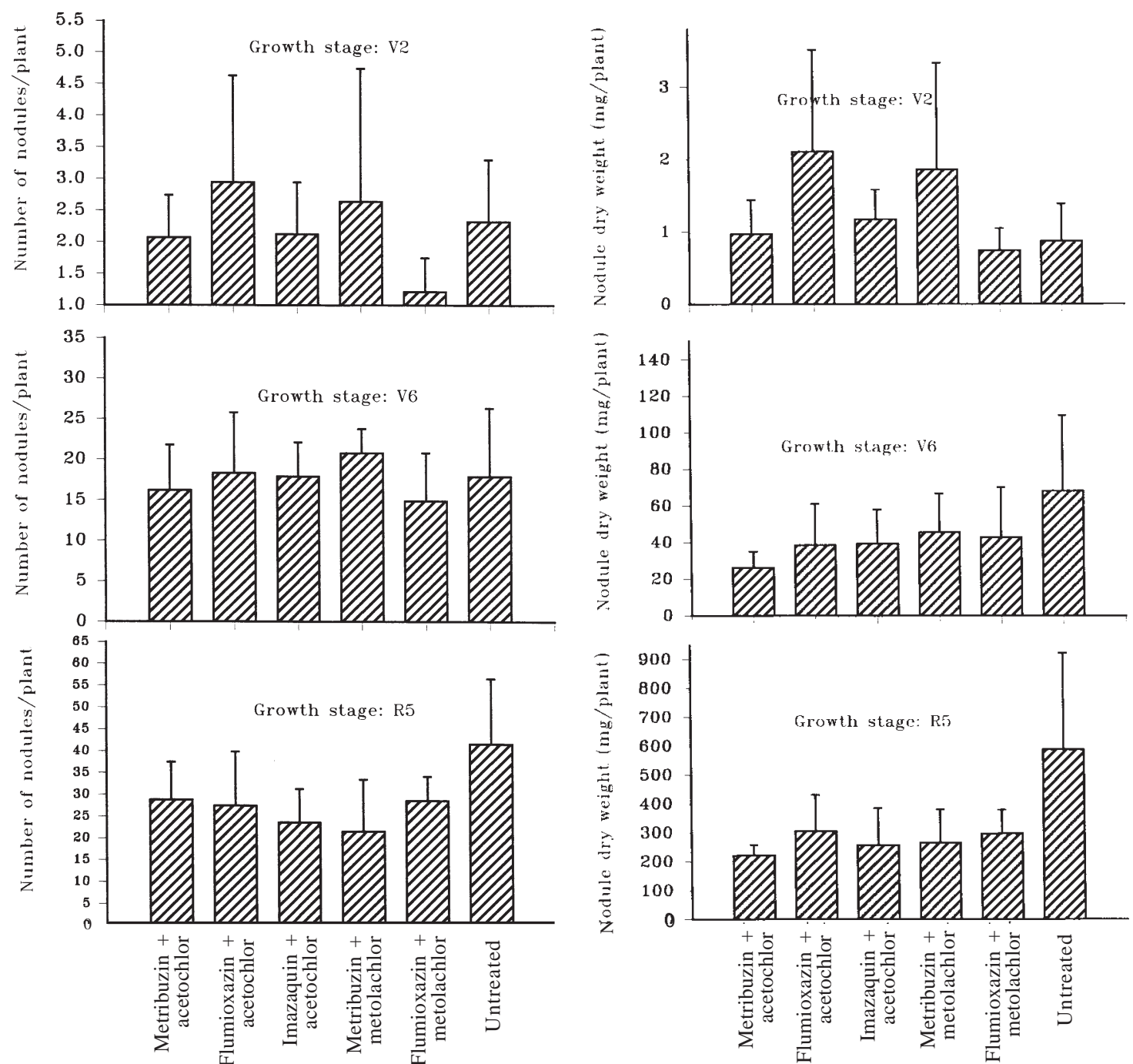

FIG. 3. Mean number and dry weight of nodules per plant of soybean cultivar A3205 inoculated with Bradyrhizobium japonicum CB 1809 at second node (V2), sixth node (V6) and beginning seed (R5) affected by herbicides applied in tank mixtures. Vertical bars are the standard error of means. 
TABLE 2. Yield, yield components and seed N, concentration and accumulation.

\begin{tabular}{lcccccc}
\hline Treatment & $\begin{array}{c}\text { Seed yield } \\
\left(\mathrm{kg} \mathrm{ha}^{-1}\right)\end{array}$ & $\begin{array}{c}\text { Pod number } \\
\left(10^{6} \mathrm{ha}^{-1}\right)\end{array}$ & $\begin{array}{c}\text { Seed number } \\
\left(10^{6} \mathrm{ha}^{-1}\right)\end{array}$ & $\begin{array}{c}\text { Seed weight } \\
(\mathrm{g} \mathrm{1000} \mathrm{seeds})\end{array}$ & \multicolumn{2}{c}{ Seed N } \\
\cline { 4 - 7 } Trifluralin & & \multicolumn{2}{c}{ Experiment 1} & $\left(\mathrm{~kg} \mathrm{ha}^{-1}\right)$ \\
Metolachlor & 2941 & 8.216 & 17.812 & 169.28 & 4.93 & 136 \\
Imazaquin & 3127 & 8.770 & 18.181 & 176.37 & 5.10 & 147 \\
Metribuzin & 2889 & 8.042 & 17.120 & 175.57 & 5.04 & 130 \\
Flumioxazin & 3057 & 8.119 & 17.787 & 175.91 & 5.15 & 143 \\
Imazathapyr & 3020 & 8.520 & 18.039 & 174.24 & 5.16 & 136 \\
Chlorimuron ethyl & 3031 & 8.359 & 18.289 & 174.20 & 5.23 & 139 \\
Acetochlor & 3038 & 7.864 & 17.555 & 180.48 & 4.90 & 143 \\
Control & 2894 & 7.903 & 17.276 & 173.88 & 5.28 & 139 \\
\hline C. V. (\%) & 2689 & 6.308 & 13.950 & 185.12 & 4.99 & 123 \\
F test (p value) & 10.17 & 11.94 & 12.31 & & 4.66 & 12.69 \\
& 0,717 & 0,074 & 0,327 & 0,153 & 0.335 & 0.661 \\
\hline & & & Experiment 2 & & 115 \\
Metribuzin + acetochlor & 2700 & 7.604 & 16.196 & 173.37 & 4.91 & 112 \\
Flumioxazin + acetochlor & 2678 & 7.212 & 15.795 & 167.80 & 4.84 & 112 \\
Imazaquin + acetochlor & 2803 & 7.887 & 16.799 & 168.89 & 5.05 & 123 \\
Metribuzin + metolachlor & 2657 & 7.778 & 16.567 & 167.23 & 4.81 & 111 \\
Flumioxazin + metolachlor & 2540 & 7.203 & 15.847 & 166.94 & 4.81 & 106 \\
Control & 2708 & 8.055 & 16.674 & 171.73 & 5.17 & 121 \\
\hline C. V. (\%) & 11.01 & 8.97 & 10.71 & 5.54 & 6.24 & 13.6 \\
F test (p value) & 0.88 & 0.41 & 0.93 & 0.89 & 0.49 & 0.65 \\
\hline
\end{tabular}

mulation in seed of soybean treated with herbicides alone was $18 \%$ higher than that accumulated in seeds of plants treated with mixtures of herbicides. This seemed to be a direct consequence of the yields achieved in each case since seed $\mathrm{N}$ concentration was nearly the same in both experiments. These results suggest that the combination of two herbicides could eventually cause more damage than the use of just one.

\section{CONCLUSION}

1. Herbicides that have been used during several years and those of recent development such as flumioxazin, imazethapyr, or imazaquin, sprayed alone at the recommended rates can be used for weed control in soybean in the south eastern area of Buenos
Aires Province, without diminishing yields because of their influence on nodulation.

2. Same herbicides as above, sprayed in tank mixes at the recommended rates do not show either any significant effect on nodulation or $\mathrm{N}$ fixation that may cause influence on soybean grain yield.

\section{REFERENCES}

AKHTAR, M.; AFGHAN, S.; MAHMOOD, T.; ABBAS, G. Effect of pre and post emergence weedicides application on nodulation growth and yield of soybean at different fertility levels. Journal of Agricultural Research Lahore, v.28, p.29-37, 1990

AL-GUBOURI, A.A.; HABIB, S.A. Effect of some herbicides on nodulation of soybean (Glycine max (L) Merrill). Journal of Agriculture and Water 
Resources Research, Plant Production, v.6, p.11-26, 1987.

ANDRIANI, J.M.; ANDRADE, F.H.; SUERO, E.E.; DARDANELLI, J.L. Water deficits during reproductive growth of soybeans. I. Their effect on dry matter accumulation, seed yield and its components. Agronomie, v.11, p.737-746, 1991.

BOLLICH, K.P.; DUNIGAN, P.E.; JADI, M.W. Effects of seven herbicides on $\mathrm{N}_{2}\left(\mathrm{C}_{2} \mathrm{H}_{2}\right)$ fixation by soybeans. Weed Science, v.33, p.427-430, 1985.

DALTON, D.A. Effects of paraquat on the oxygen free radical biology of soybean root nodules. Bulletin of Environmental Contamination and Toxicology, v.48, p.721-726, 1992.

DUNIGAN, E.P.; FREY, J.P.; ALLEN, L.D.; MCMAHON, A. Herbicidal effects on the nodulation of Glycine $\max$ (L.) Merrill. Agronomy Journal, v.64, p.806-808, 1972.

EYHERABIDE, J.J. Evaluation of pre-emergent applications of flumioxazin alone and with imazaquin and imazethapyr against weeds in soybeans. Tests of Agrochemicals and Cultivars no 14. Annals of Applied Biology, v.122, p.62-63, 1993. Suppl.

EYHERABIDE, J.J. Evaluation of pre-emergent herbicides applications against Digitaria sanguinalis in no tillage soybeans. Tests of Agrochemicals and Cultivars no 16. Annals of Applied Biology, v.126, p.66-67, 1995. Suppl.

FEHR, W.R.; CAVINESS, C.E. States of soybean development. Ames: Iowa State Univ., 1977. 12p. (Iowa Cooperative Extensive Service. Special Report, 80).

FISHER, R.F.; LONG, S.R. Rhizobium-plant signal exchange. Nature, v.357, p.655-659, 1992.

GIORDA, L.M. La soja en la Argentina. In: GIORDA, L.M.; BAIGORRI, H.E. (Eds.). El cultivo de la soja en la Argentina. San Juan: INTA, 1998. p.11-26.

GONZÁLEZ, N.S. Dinámica de la fijación de nitrógeno en soja, en suelos con alta fertilidad nitrogenada. Mar del Plata: Universidad Nacional de Mar del Plata, Facultad de Ciencias Agrarias, 1994. 62p. Tesis Magister Scientiae.
HAN, Y.S.; OH, J.H. Effects of herbicide application on growth and the nodulation in soybean. Korean Journal of Crop Science, v.34, p.303-309, 1989.

KEYSER, H.H.; SOMASEGARAN, P.; BOHOLOOL, B.B. Rhizobial ecology and technology. In: METTING JUNIOR, B. (Ed.). Soil microbial ecology. New York: Marcel Dekker, 1993. p.205-226.

K U CEY, R.M.N.; C H A I W A N A K U P, P .; ARAYANGKOOL, L.; SNITWONGSE，P.; SIRIPAIBOOL， N.; WADISIRISUK, P.; BOONKERD, N. Nitrogen fixation $\left({ }^{15} \mathrm{~N}\right.$ dilution) with soybeans under Thai field conditions. Plant and Soil, v.108, p.87-92, 1988.

MONTGOMERY, D.C. Design and analysis of experiments. New York: John Wiley \& Sons, 1984. 537p.

MORAES, R.; LOPES, N.F.; SILVA, E.A.M. da; RODRIGUES, J.J. do. Tolerance and nodulation in soybeans (Glycine max (L) Merrill) cultivated on two substrata and treated with four doses of metribuzin. Revista Ceres, v.36, p.492-506, 1989.

MOYER, J.R. Soil organic matter, moisture, and temperature: effect on wild oats control with trifluralin. Canadian Journal of Plant Science, v.59, p.763-768, 1979.

RENNIE, R.J.; DUBETZ, S. Effect of fungicides and herbicides on nodulation and $\mathrm{N}_{2}$ fixation in soybean fields lacking indigenous Rhizobium japonicum. Agronomy Journal, v.76, p.451-454, 1984.

RENNIE, R.J.; DUBETZ, S.; BOLE, J.B.; MUENDEL, H.H. Dinitrogen fixation measured by ${ }^{15} \mathrm{~N}$ isotope dilution in two Canadian soybean cultivars. Agronomy Journal, v.75, p.640-644, 1982.

UNITED STATES. Department of Agriculture, Soil Survey Staff. Key to Soil Taxonomy. 7.ed. Washington DC: U.S. Government Printing Office, 1996. 644p.

YUEH, L.Y.; HENSLEY, D.L. Pesticide effect on acetylene reduction and nodulation by soybean and lima bean. Journal of the American Society for Horticultural Science, v.118, p.73-76, 1993. 